Original article

\title{
PALESTINIAN LOCAL GOVERNMENT: ISSUES OF LEGAL AND INSTITUTIONAL FRAMEWORKS
}

\section{Feras Ali Qawasmeh ${ }^{1}$, Kuppusamy Singaravelloo², Raja Noriza Raja Ariffin ${ }^{3}$}

\author{
${ }^{1} \mathrm{PhD}$ of Public Administration, Department of Administration and Politics, \\ University of Malaya, Kuala Lumpur, Malaysia; Chief Editor in the Department \\ of Israeli Settlements at the Vision Centre for Political Development, Istanbul - Turkey. \\ Address: University of Malaya, Jln Profesor Diraja Ungku Aziz, \\ 50603 Kuala Lumpur, Federal Territory of Kuala Lumpur, Malaysia \\ Email: ferasaliqawasmeh@gmail.com (Corresponding Author) \\ ${ }^{2}$ Associate Professor, Department of Administrative Studies and Politics, Faculty \\ of Economics \& Administration, University of Malaya, Kuala Lumpur, Malaysia. \\ Email: kuppusamy_s@um.edu.my \\ ${ }^{3}$ Associate Professor, Department of Administrative Studies and Politics, Faculty \\ of Economics \& Administration; and Deputy Director, International Institute \\ of Public Policy and Management, University of Malaya, Kuala Lumpur, Malaysia. \\ Email: rnoriza@um.edu.my
}

\begin{abstract}
In the public administration field, the legislative, executive and judicial frameworks should be consistent. The institutional framework of the Palestinian local government, however, seems largely impacted by an incoherent legal framework. Against this backdrop, this study describes the current local government institutional framework. Secondly, this study investigates the current issues relating to the legal and institutional frameworks of the Palestinian local government.

A qualitative research approach was adopted to collect data in order to achieve the objectives of the study. The present research utilizes a combination of primary and secondary data. Nine interviews were conducted to gather the primary data, while scholarly works and government documents were used for gathering secondary data.

The results show that fully governmental institutions are the most active within the institutional framework while non-governmental institutions are less active. The results also show that the primary obstacle for an efficient legal framework is due to previous laws, overlapping powers and weak legal practices. Furthermore, the institutional framework suffers from deformed structure and weak integration.

The discussion section revealed that the current local government system can be best described as a "Chaotic Hybrid System". When comparing the empirical results with the theoretical concepts, it is indicated that the current local government structure reflects the Public Choice Theory perspective, which advocates for horizontal and vertical
\end{abstract}


fragmentation. However, the Israeli occupation and international funds seem to contribute to complicating the fragmentation of the structure. The structure hence could be described as "Altered Fragmented Structure".

Keywords: local government; administrative, legal; structure; fragmentation; public choice, Palestine.

Acknowledgment: the researchers would like to thank all those who participated in this research.

For citation: Feras Ali Qawasmeh, Kuppusamy Singaravelloo and Raja Noriza Raja Ariffin (2021) 'Palestinian local government: Issues of legal and institutional frameworks', Public Administration Issues, 6 (Special Issue II, electronic edition), pp. 146-171 (in English). DOI: 10.17323/1999-5431-2021-0-6-146-171.

JEL Classification: H11; H76; L32; M38; O43.

\section{Introduction}

Palestine was ruled by the Ottoman Empire from 1516 until 1917 and by Britain from 1917 to 1948. In 1948, Israel occupied 78 percent of Palestine, declaring its stake in these conquered lands. The only unoccupied Palestinian regions were the West Bank (WB) and the Gaza Strip (GS) which represented 21 and 1.3 percent of Palestine, respectively. From 1948 to1967, the WB was ruled by Jordan while the GS was under Egyptian control. Furthermore, Israel occupied the WB and GS in 1967 imposing a military administration on the two regions. Later in 1993, the Oslo Accords were signed between Israel and the Palestinian Liberation Organization (PLO). As a result, the PLO recognized Israel as a state and in return, Israel recognized the PLO as the Palestinian representative. Subsequently, the Palestinian National Authority (PNA) was established in 1994.

There were many local government (LG) laws issued during the Ottoman, British, Jordanian, Egyptian and Israeli rule over Palestine. Significant founding laws include the Province Law 1864, the Provincial Administration Law 1871, the Municipality Law 1877, The Local Council Law 1921, the Municipality Law 1934 and the Jordanian Municipality Law 1954. In addition, hundreds of Israeli military orders have contributed to shaping the LG system (Jarbawi, 1996, pp. 35-110; Shtayyeh and Habas, 2004, p. 102; Isma'il, 2005, pp. 59-84; Hsiba, 2006, pp. 38-57; Al-Habil, 2008, pp. 77-119; Salameh, 2009). Centralization of autonomy dominates the Palestinian governmental system. However, the PNA's issuing of Local Authority Law 1997 attempted to decentralize the LG system to a considerable extent. As indicated in the Local Authority Law 1997, the legal framework is the basic determinant of the LG institutional framework. Therefore, A consistent legal and institutional framework makes for an efficacious LG (Bodansky, 1995; Hannam and Boer, 2002; Penning et al., 2002). Granting that, many studies discern a gap between the institutional framework (which results from the Local Authority Law 1997) and the one being applied (Jarbawi, 1996, p. 107; Isma'il, 2005, p. 101; Hsiba, 2006; Al-Habil, 2008, pp. 8-9; Salameh, 2009, pp. 125-128). The PNA was understood to reinforce the 
centralization system. Nevertheless, the aforementioned studies have neither comprehensively provided an understanding of the bigger picture of the institutional framework, nor have they elaborately investigated the issues relevant to both the legal and institutional frameworks. Although the current institutional framework can be rhetorically indicated, it is difficult to elaborate its actual functions and structure. Indeed, the Palestinian context is unstable and dramatically changing. Against this context, this paper aims to answer the following questions:

1. What is the institutional framework for the Palestinian Local Government?

2. What are the main legal and institutional issues of the Palestinian local government?

Although theoretically similar legal and institutional frameworks exist in both the WB and GS, internal division between Hamas (the Islamic Resistance Movement) and Fatah (the Palestinian National Liberation movement) in 2007 has resulted in the area being administered by two different governments. The government in the WB is controlled mainly by Fatah and the GS is controlled by Hamas. This study focuses only on the WB for several reasons. Following the control of Hamas over the GS, the GS fell under an Israeli siege, which eventually created a complicated situation and a relatively different context relative to the WB. As a consequence, data is more accessible in the WB in comparison to the GS. Furthermore, communication with GS officials may engender a security threat (i.e., Israeli occupation force violence).

\section{Theoretical perspectives}

The Public Administration field has three interrelated branches: legislative, executive, and judicial (Rosenbloom, 1986). The separation of powers is usually understood as a constitutional doctrine that separates government into autonomous institutions responsible for performing different functions. Legislative power creates laws, the executive power enforces laws, and the judicial power interprets laws (Klassen and Brown, 2018; Zaring, 2020). In democratic countries, the separation of powers is typically implemented in conjunction with a system of checks and balances which are often included within a constitution, for each branch to counter and restrain the power of the other branches (Humphreys, 2021). However, tension between the three powers occurs very often, especially in unstable states. It is observed in some fragile states that one power over-controls other powers (Salter, 2021).

Generally, public administration is "being anchored in both functions and institutional structure" (Rosenbloom, 2013, p. 386). In other words, it defines what activities should be practiced and who should do them (Penning et al., 2002). Perhaps the most well-known public administration frameworks are the top-down (centralization) and bottom-up (decentralization) systems (Birkland, 2006).

In the centralized system, the government is the sole decision maker and service provider whereby a high level of authority hierarchy exists (Andrews et al., 2007): Even with LG operation, the central government can control local units and determine intergovernmental relationships (Singaravelloo, 2013; Panday, 2017), income and expenditure, administrative regulations, political ideology, the way to deliver services, and the capacities of local representatives (Goldsmith and Page, 1987, 
p. 23; Goldsmith, 2002). Conversely, the decentralized system allows for the transfer of power, authority, resources and accountability from the central government to the LGs (UNDP, 1997; Panday, 2011). Decentralization contributes to key elements of good governance. The most important aspect involves the people's participation in decision-making (local elections); developing people's capabilities; and enhancing government responsiveness, accountability, and transparency (UNDP, 1997).

LG refers to the lower tier of government that has autonomy and operates within a restricted area (Marshall, 1965, p. 8). What distinguishes LG from the central government is the principle of subsidiarity. It refers to the notion that public matters should be dealt with by local authorities that are closest to the citizens. They have better access to citizens' information and more capabilities in service delivery (Cass, 1992).

LGs have two primary functions: one is to provide local aspirants a voice for decentralized governance (local democracy); while simultaneously the other involves providing an efficient mechanism of service delivery to the communities (local efficiency) (Aulich, 1999, 2005). However, a trade-off exists between local democracy and local efficiency (Burdess and O'Toole, 2004; Hearfield and Dollery, 2009). Local democracy emphasizes the notion of representativeness, responsibility and accountability, often termed with respect to political and social norms. Nevertheless, local efficiency requires reinforcing structural efficiency to maximize the benefits and minimize the costs (Aulich, 1999).

The public choice theory perspective (sometimes called polycentrists or localists) advocates for horizontal and vertical fragmented structure. The former refers to the proliferation of LGs within the same tier of LG. It allows inhabitants to be closer to their elected officials and it enables them to better participate in civic life (Tiebout, 1956; Ostrom, 1972; McDonnell, 2019). This feature seems to match with the local democratic model (Dollery, 2010). Nevertheless, vertical fragmentation separates the process of service production from service provision (tiers of the LG). It is argued that the horizontal and vertical application of public choice theory leads to increased efficiency (Yang, 2021). Figure 1 visualizes the vertical and horizontal fragmented structure.

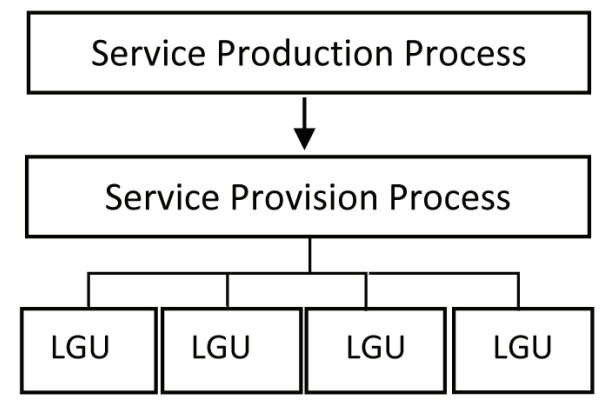

Figure 1: Local government fragmented structure.

Source: Compiled from McDonnell (2019); E. Ostrom (1972) and Tiebout (1956).

On the other hand, the institutional reform movement perceives horizontal and vertical fragmentation of LG as a wasteful duplication of efforts that result 
in inefficiency. Therefore, institutional reformers advocate for the consolidation notion (Committee for Economic Development, 1970; Ostrom, 1972; Advisory Commission on Intergovernmental Relations, 1974). A single multifunctional LG would produce and provide the same service more efficiently if fewer tiers and units of LG existed. Furthermore, fragmented structure creates a "common-pool problem" in which the same service might be the responsibility of multiple LGs (Berry, 2008, 2009, pp. 148-179). Additionally, larger LG entities "enhance LG capacity, thereby improving the range and quality of local service provisions as well as its bargaining abilities with higher tiers of government" (Dollery, 2010, p. 117). Noticeably, institutional reform reconciles with the local efficiency model. Figure 2 visualizes the vertical and horizontal consolidated structure.
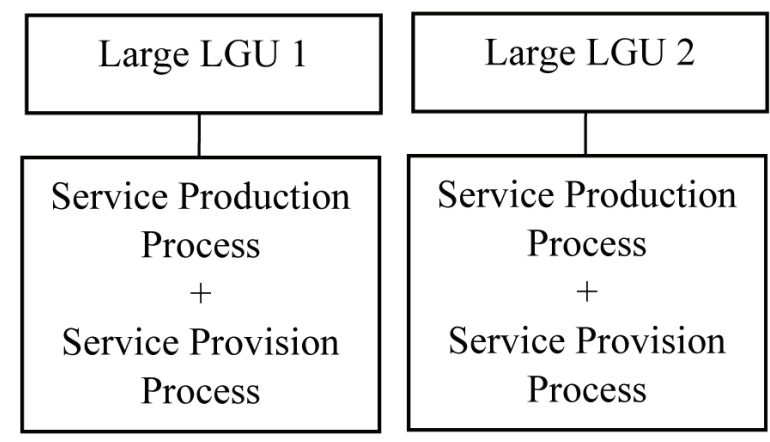

Figure 2: Local government consolidated structure.

Source: Compiled from Advisory Commission on Intergovernmental Relations (1974); Committee for Economic Development, (1970); E. Ostrom (1972) and Dollery (2010).

Nevertheless, other scholars assume that there is no trade-off between local democracy and local efficiency; the size of the municipal council is negatively correlated with municipal efficiency and democracy (Boyne, 1992, 1995). Therefore, smaller local authorities have better local democracy and efficiency. Other studies have found that bigger LGs are more democratic and efficient (Soul and Dollery, 2000). Obviously, fragmented versus consolidated structure is still a debatable issue.

\section{Methodology}

The present exploratory study seeks to generate a novel perspective relating to two main objectives: The first is to explore the current Palestinian LG institutional framework. The second objective is to explore issues associated with both legal and institutional frameworks at the Palestinian LG level. For the first objective, secondary data from relevant documents and studies were collected and analyzed. For the second objective, a qualitative approach was used via adopting an interview instrument used in order to access the required data. At a philosophical level, the present study belongs to the interpretivism paradigm meaning that different interviewee perspectives were articulated in order to help construct broader insights (Saunders, Lewis and Thornhill, 2009). 
Nine interviews were conducted in order to collect the primary data. A quota sampling strategy was adopted in order to determine who would be interviewed. "The quota sample improves the representations of particular strata (groups) within the population, as well as ensuring that these strata are not over-represented" (Sharma, 2017, p. 751). Basically, the population of study was first classified into three main categories in accordance with the institutional framework shown in Figure 4. This framework is an indication of achieving the first study objective. Hence, the first study objective was achieved, then, interviewed representatives were selected based on the institutional framework components. In addition, an experts' opinions category was also included. Notably, non-governmental institutions were not counted as a category because these institutions do not contribute significantly to the LG system. They are also difficult to identify (Krunz, 2009; Sabri, Jaber and Hanya, 2010). There is no known NGO that consistently works within a Palestinian LG. Since fully governmental and semi-governmental institutions are most active in LGs, representatives of all institutions within this category were interviewed. Additionally, two interviews were conducted to represent the "Interrelated Ministries" category. The ministries were selected based on their vital coordinating role with the fully governmental institutions. Therefore, the Palestinian Water Authority (PWA) and the Ministry of Planning and Finance (MoPF) were selected. Furthermore, an interview of a LG expert qualified as the fourth category. Figure 3 shows how the represented institutions were selected, applying the four main categories and other sub-categories. It is worth mentioning that although 10 interviews were initially planned, the present author was unable to interview an APLA representative, so the figure dropped to nine.

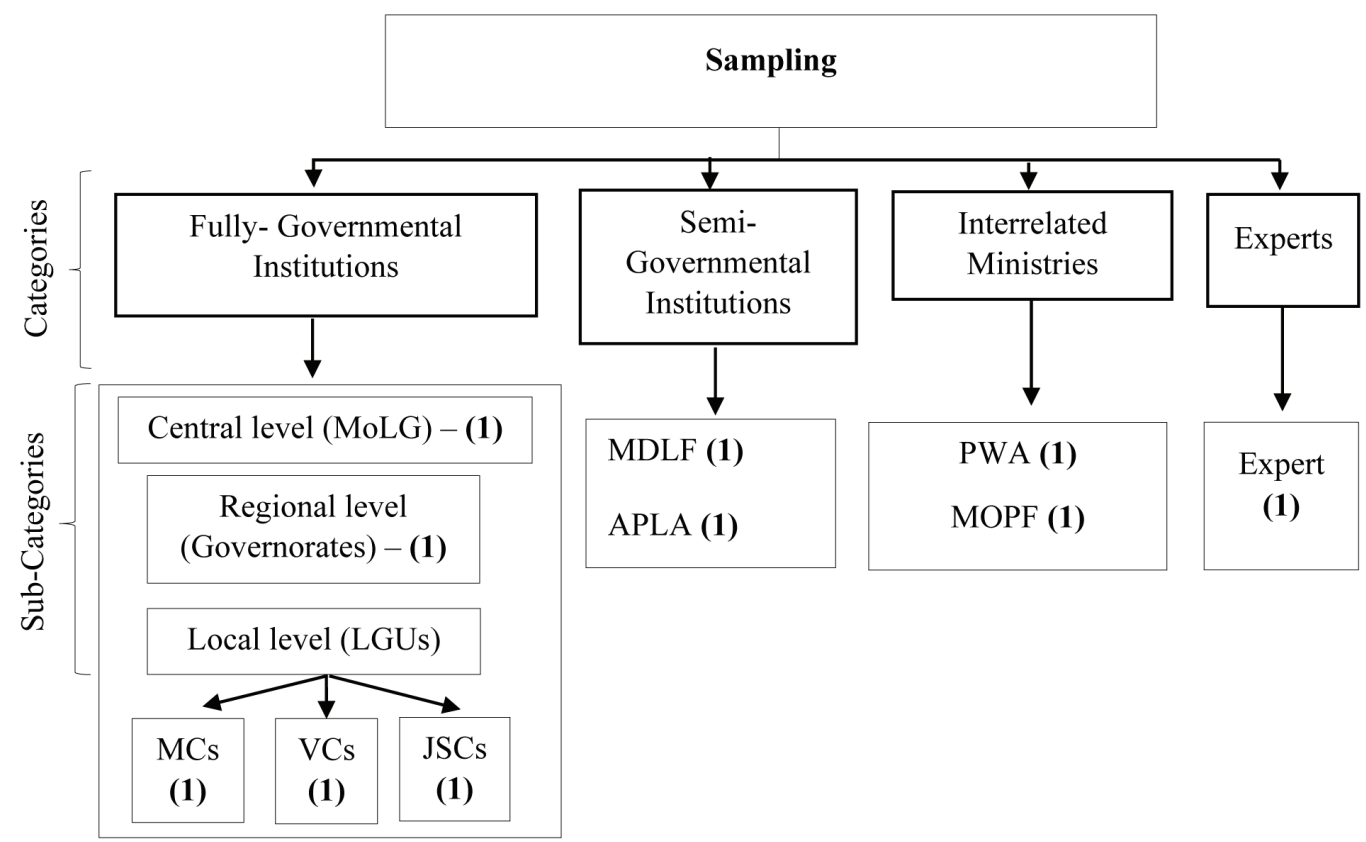

Figure 3: Representative institutions selected by quota sampling.

Source: Compiled by the authors. 
Table 1 indicates information about interviewees, their positions and affiliated institutions. Abbreviations are given for each institution's representative to be referred to in the analysis section.

A semi-structured technique was considered for data collection in order to allow for asking some pre-determined and follow-up questions. Scholars such as Mackenzie (2020) advocate this semi-structured technique as one of the best techniques used during the interviews. As consistent with the study objectives, the main pre-determined themes were about characteristics of the Palestinian LG, related issues, impacting factors and suggestions for reform. Other sub-themes were developed throughout the interviews. All interviews were conducted in Arabic via a one-hour (approx.) phone call. Following this, all answers were transcribed in Arabic and analysed manually after identifying the main themes and codes. Various patterns of answers were observed. Practically, two main codes were identified: issues related to the legal framework, and issues relating to the institutional framework. Subsequently, sub-codes were identified as shown in the analysis of the interview data section. After the analysis was completed in Arabic, the findings were translated into English.

Table 1

\section{Information about Interviewees}

\begin{tabular}{|c|c|}
\hline Position and affiliated institutions & Abbreviation \\
\hline \multicolumn{2}{|l|}{ Fully Governmental Institutions } \\
\hline Former Minister for Ministry of Local Government (MoLG) & FG1 \\
\hline $\begin{array}{l}\text { Former Governor of Hebron Governorate } \\
\text { Ex-Minister for Ministry of Local Government (MoLG) }\end{array}$ & FG2 \\
\hline Member of Hebron Municipal Council & FG3 \\
\hline Member of Yetta Municipal Council & FG4 \\
\hline $\begin{array}{l}\text { Head of the Joint Services Council for Northwest of Nablus Villages } \\
\text { Head of Sebastia Village Council }\end{array}$ & FG5 \\
\hline \multicolumn{2}{|l|}{ Semi-Governmental Institutions } \\
\hline $\begin{array}{l}\text { The Operating Manager for Municipal Development and Lending } \\
\text { Fund (MDLF) }\end{array}$ & SG1 \\
\hline $\begin{array}{l}\text { The Operating Manager for Association of Palestinian Local } \\
\text { Authorities (APLA). }\end{array}$ & SG2 \\
\hline \multicolumn{2}{|l|}{ Interrelated Ministries } \\
\hline $\begin{array}{l}\text { Secretary General of Planning and Administrative Development } \\
\text { Ministry }\end{array}$ & IM1 \\
\hline Former Minister of Palestinian Water Authority (PWA) & IM2 \\
\hline \multicolumn{2}{|l|}{ Experts } \\
\hline $\begin{array}{l}\text { Senior researcher and expert of local government at the Palestinian } \\
\text { Liberation Organization (PLO) research centre }\end{array}$ & EX1 \\
\hline
\end{tabular}

Source: Compiled by the authors. 


\section{Findings}

This section was written based on secondary data to fulfil the first research objective that aimed to indicate the institutional framework of the Palestinian local government.

\section{Palestinian Local Government: Institutional Framework}

The Palestinian institutional framework has been organic and altering dynamically since the establishment of the PNA in 1994. Indeed, no document or study was found to demonstrate the comprehensive institutional framework. Therefore, it is essential to display the big picture according to the official documents and relevant studies. The Palestinian LG institutional framework comprises of three different types of institutions: fully governmental, semi-governmental, and non-governmental.

Fully governmental institutions have three levels; the central, the regional and the municipal (Signoles, 2010). The central institution is reflected in the Ministry of Local Government (MoLG), with representative directorates in the $11 \mathrm{WB}$ governorates and one in the GS (MoLG, 2020). Article 2 of the Local Authority Law 1997 states that the role of MoLG is to formulate general policies for local councils, supervise the functions of different local councils - public projects, budgeting, finance, organizational and legal affairs - and to accomplish the technical and administrative work related to regional planning.

The regional level is made up of governorates (or Muhafazat). Upon the establishment of MoLG, Palestinian territories were divided into 16 Governorates, 11 in the WB and five in the GS (MoLG, 2020). Structurally, irrespective of the WB or GS, they are supervised by the Presidency Office. A governor is nominated directly by the president of the PNA and represents the central authority.

Additionally, he has power in vital areas in which he oversees security; municipal and village councils, and he coordinates other state services such as health, education, and transportation (Salameh, 2009, p. 34). There is no clear legal basis, however, in which to regulate the governor's activities (Signoles, 2010, pp. 21-22).

The local level consists of different local government units (LGUs) which are the Municipal Councils (MCs), Village Councils (VCs), and Joint Services Committees (JSCs).

The latter is a combination of various VCs (CEC, 2017). Palestinian refugee camps have their own local councils as well, but they are beyond the mandate of the MoLG (Al-Habil, 2008). The main role for all LGUs is to provide civil and infrastructure services to Palestinian inhabitants (e.g., water, wastewater, electricity and paving roads). Yet, education, health and social affairs are beyond their mandate (The World Bank, 2017b, p. 18). MCs provide services to Palestinian inhabitants who reside in the main cities of governorates. However, VCs and JSCs provide the services for those who reside in the villages. Table 2 indicates the distribution of local authorities in Palestinian Territories. 
Table 2

The distribution of local authorities in Palestinian territories

\begin{tabular}{|l|c|c|c|}
\hline \multicolumn{1}{|c|}{ Local Authority } & West Bank & Gaza Strip & Total \\
\hline $\begin{array}{l}\text { Municipality (Municipal } \\
\text { Councils) }\end{array}$ & 126 & 25 & 151 \\
\hline Village Councils & 280 & 0 & 280 \\
\hline Camp Council & 20 & 8 & 28 \\
\hline Total Number of LGUs & & & 459 \\
\hline
\end{tabular}

Source: The Central Elections Commission, (2019).

Semi-governmental institutions include the Municipal Development and Lending Funds (MDLF) and the Association of Palestinian Local Authorities (APLA). The MDLF is a semi-governmental institution established in 2005 by the Council of Ministers Decree No. 32/36/09. As stated on the MDLF website (MDLF, 2020), its main objective is to "encourage the flow of financial resources from the PNA and various donors to the LGUs and other local public entities to improve the delivery of local infrastructure and municipal services, to promote economic development, and improve municipal efficiency and accountability". Furthermore, the APLA was founded in 1997 and it is assumed to be the highest framework in which LGUs can share experience and knowledge related to community developments. Its aims are to unite, defend and support the LGUs' efforts to become more efficient, independent, and citizen oriented local authorities. Moreover, it provides a means of dialogue between the central government and LGUs (Abdul Ati, 2005; Salameh, 2009, p. 78).

Non-governmental institutions include the private sector and non-profit organizations (NGOs) (Salameh, 2009, p. 81). The role of the private sector in planning for the local level is modest and inefficient (Krunz, 2009; Sabri, Jaber and Hanya, 2010). There are many reasons which support this conclusion. The existing laws and regulations that do not encourage this type of partnership, are among the top reasons.

There is no clear strategy at the governmental level to deal with the private sector, which in turn has led to creating weak public awareness about the importance of private sector partnership among LGUs (New Vision Firm, 2009). The private sector, however, is more involved in the implementation process (Sabri, Jaber and Hanya, 2010). Nearly 12.6 percent of LGU-run projects are in partnership with the private sector (large municipalities) (New Vision Firm, 2009).

Unlike the private sector, NGOs have no role in planning or implementing LG projects and programs. Moreover, they have a limited role in providing financial resources to projects (Krunz, 2009; Sabri, Jaber and Hanya, 2010). According to the MDLF Report (2018b), a total of eight NGOs submitted their applications to MDLF expressing their interest to establish partnerships with 
LGUs. As these applications need to be assessed by MDLF, currently the results have yet to be known. The Oslo Accords were a turning point for NGOs because foreign donors were able to channel their funds to the PNA (Salameh, 2009, p. 288). Furthermore, fully governmental institutions interfere with various ministries and authorities (The World Bank, 2017b, p. 18). The interrelated responsibilities are indicated in Table 3.

Table 3

\section{The interrelated responsibilities between Palestinian ministries and LGUs}

\begin{tabular}{|c|c|}
\hline Ministry / Authority & Interrelated Responsibilities \\
\hline The Palestinian Water Authority (PWA) & $\begin{array}{l}\text { - Coordination regarding water supply, } \\
\text { wastewater disposal and planning }\end{array}$ \\
\hline The Palestinian Energy Authority (PEA) & $\begin{array}{l}\text { - Coordination regarding electricity supply } \\
\text { and planning }\end{array}$ \\
\hline Ministry of Planning and Finance (MoPF) & $\begin{array}{l}\text { - Sharing revenues between MoPF and LGUs } \\
\text { - Coordinating with donors regarding projects } \\
\text { funds }\end{array}$ \\
\hline $\begin{array}{l}\text { The Palestinian Environmental Quality Authority } \\
\text { (PEQA) }\end{array}$ & $\begin{array}{l}\text { - Coordinating affairs related to all } \\
\text { environmental issues }\end{array}$ \\
\hline $\begin{array}{l}\text { Ministry of Public Works and Housing } \\
\text { (MoPWH) }\end{array}$ & $\begin{array}{l}\text { - Proposing plans and designs of regional roads } \\
\text { - Coordination of land acquisition by LGUs for } \\
\text { public projects }\end{array}$ \\
\hline The Palestinian Land Authority (PLA) & $\begin{array}{l}\text { - Facilitating land surveying, transactions, } \\
\text { and registrations }\end{array}$ \\
\hline Ministry of Labor (MoL) & - Licensing industrial establishments \\
\hline Ministry of Health $(\mathrm{MoH})$ & $\begin{array}{l}\text { - Approving building permits according } \\
\text { to environmental health conditions } \\
\text { - Monitoring public health }\end{array}$ \\
\hline Ministry of Education (MoE) & - Maintaining educational and cultural buildings \\
\hline Ministry of Tourism and Antiquities (MoTA) & $\begin{array}{l}\text { - Coordination regarding antiquities and } \\
\text { historical sites located within LGU boundaries }\end{array}$ \\
\hline
\end{tabular}

Source: Al-Habil (2008); Ezbidi (2010); Hassiba (2006); Salameh (2009) and The World Bank (2017).

Figure 4 outlines the LG institutional framework. It is important to note that interrelated ministries have different levels of coordination and cooperation with LGUs, depending on the type of service, project, or institution. The water provision service, for example, is highly interrelated with the function of LGUs. Contrarily, the electricity service has recently been privatised and there has been little coordination with LGUs. 


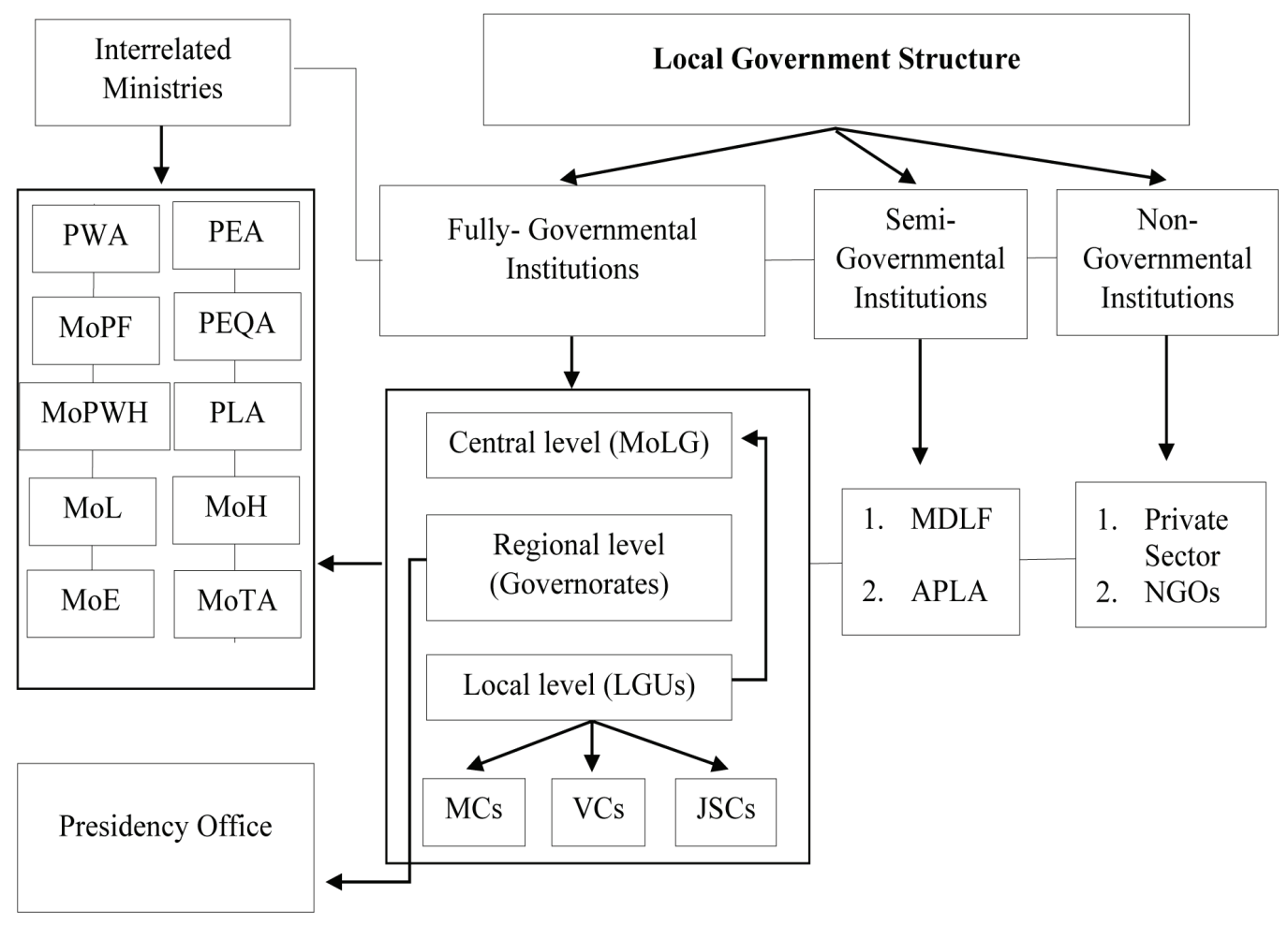

Figure 4: Institutional framework of the Palestinian local government.

Source: Compiled by the authors.

\section{Issues of Legal Framework}

\section{Previous Laws}

The previous laws, which formed the Palestinian LG system, have remained relatively active. Hence, this has contributed to the existing gap between the 1997 Law and the current institutional framework. The 1997 law attempted to overcome the weaknesses of previous laws. However, it seems that the decision makers default to previous laws due to sheer convenience rather than taking the trouble to draft new ones. This notion was asserted by different interviewees, mainly those representing the fully governmental institutions, whether at the macro or micro level.

"I, as a specialist in public administration, with other legal advisers have proposed a modern law that was based on the idea of financial and administrative decentralization. However, it was rejected by the Palestinian parliament. Therefore, the legal committee of the Palestinian parliament proposed a traditional local authority law that was just copied and pasted from the Jordanian and Egyptian law. These laws present a local administration framework, not LG system. Nevertheless, they were adopted". (FG2)

"The current law is almost a carbon copy of the Jordanian Law". (FG4) 
What further complicates the legal framework is the attribution to multiple laws. The existence of multiple laws reflects the logic of the particular ruling power in a specific context. That context, however, may prove antiquated and ill-suited for the current one:

"The multiplicity of laws, including the Ottoman, British, Jordanian, Egyptian, and lastly the Palestinian have led to a gap between the legislative and administrative system, and implementation". (EX1)

"We have laws, but we do not apply them as they are quoted from previous laws such as the Jordanian one. We need an alternative for these as we live under occupation." (FG5)

\section{Overlapping Powers}

Other than the LG Law, the PNA issued other laws for various ministries. The momentous PNA-issued Water Law 2014 withdrew the water provision service from the LGUs. Subsequently, the 2014 law, if fully applied, would restructure the LG institutional arrangements and functions. As observed from different interviews, the 2014 Law was perceived as a means to weaken the role of LGUs. There is still an on-going conflict between the PWA and MoLG.

"The PWA administrates the water and sanitation services according to the Water Law 2014. However, the MoLG is, according to the 1997 Law, responsible for water and sanitation services." (IM2)

"If the provision of water and sanitation services are withdrawn from us, what services we shall provide, especially that the provision of electricity service was, despite it being our responsibility, withdrawn from us and given to private electricity companies." (FG4)

"The Water Law 2014 did not protect the property of local councils." (FG2)

At another level, governorates engage in the work of LGUs. However, no law is found to give them the power of engagement. Although LGU structure and function can be theoretically explained, ambiguous and far-reaching governorate power makes the identification of LGU function difficult to ascertain. The following excerpt defines the powers of governorates:

"Governors directly follow the president, they have security and supervisory powers, they are also to evaluate the development needs within governorates. For example, they are the ones who prepare the development plan, not mayors. However, local councils are according to the law the ones engaged with development roles. The governor has power from the president but does not have capability on the ground while local councils have more capabilities." (EX1)

\section{Weak Legal Practices}

It appears that most interviewees agreed on the notion that LG reform requires alterations and updates in laws, regulations, and policies. However, the deactivation of the Palestinian Legislative Council constitutes an important challenge: 
"... The main obstacle is the absence of Palestinian Parliament. Therefore, you cannot formulate your own legal system. We are restricted from going for guidelines and regulations. This situation disrupts the administrative and legal development of $L G^{\prime \prime}$. (EX1)

Indeed, after Hamas won the election in 2006 and gained the majority in the Palestinian Parliament, Israel arrested all parliament representatives of Hamas in the WB, which led to the disruption of the Parliament. Moreover, the Palestinian president Mahmud Abbas had dissolved the Palestinian Parliament by the end of 2018. However, despite the absence of the Palestinian Parliament, the Palestinian government can issue "decrees", which can be as effective as laws. This feature, however, is not always utilized:

"We, in the MoLG have taken many administrative decisions which were then implemented. However, these decisions have sometimes become inactive when a new successor comes in, we need to legalize our decisions to make them "decrees. We almost do not do that... In my time we have decided to apply the economic decentralization, but this did not continue as we did not legalize it as law (decree)". (FG2)

In addition to the issuance of decrees, the Cabinet of Ministry can also issue regulations. Nevertheless, this power seems to be ignored. For, example, even though the Water Law 2014 appeared in some of its items to withdraw service from LGUs, the implementation of the law should have been followed by newly issued regulations to arrange the coordination between different institutions, yet this did not happen:

"To avoid overlapping with other previous laws, after issuing a law, it should be followed by issuing detailed regulations which help in implementation. This did not take place with the Water Law 2014. Thus, LGUs now have two laws in regards with water; the Water Law 2014 and the Local Authority Law 1997." (IM2).

"According to the Water Law 2014, the Water Sector Regulatory Council(WSRC) is a new independent council that seeks to monitor local councils and provide licences to initiate new water entities. However, due to not issuing relevant regulations from the Water Authority, the WSRC could not fulfil its role." (FG4)

The other problem of legal practices seems rooted in a lack of vision that shapes their essence:

"We lack a comprehensive vision, supreme policies, and a grand strategy. These come before issuing laws. Therefore, even if we have regulations to implement the related laws, the problem exists before that.... When the bigger picture is clear, this creates a system for good policies... There are laws but these are not updated". (SG1) "We don't have clear and consistent policies; we don't know how the amount of water was determined for us." (FG3) 


\section{Institutional Framework}

\section{Deformed Structure}

The Local Authority Law 1997 represents the basic legal framework that constitutes the LG institutional arrangements. Article 3, Item 1 of the law conceives local authority as a body that has financial and functional independence and powers according to the provision of Law. It is also stated in Article 3, Item 2 that a local authority council shall be elected by the people (PNA, 1997).

Some interviewees asserted that the 1997 Law has to a large extent presented a decentralized system. The current system, however, does not necessarily fully reflect the spirit of the 1997 Law. Indeed, three interviewees agree that actual application does not reflect a decentralized structure:

"As for the 1997 Law, it is good and gives the local authorities the necessary powers. However, on the ground, we practice centralization." (FG1)

Nevertheless, determining what structure is being implemented appears to be a challenging task. Some believe that it has the characteristics of both centralization and decentralization:

"The LG structure is complex; it is decentralized in the sense that local councils" representatives are being elected by people. Indeed, powers are taken away by people due to the election not because this reflects the government policies". (SG1)

Despite the perspective that the spread of LGUs is a clear implication of decentralization, the number of LGUs is excessive in the WB, reaching 426 . This fact is also perceived as a detrimental to the overall performance of local governance:

".... the huge number of service providers weaken the management process". (FG3)

"The huge number of local councils is (a) very serious problem." (SG1)

In response to the fragmentation of LG structure, various interviewees, particularly ones representing the macro levels (MoLG, PWA and WSRC), advocate for LGU consolidation. It is believed that consolidation would improve service delivery. However, there are various challenges when attempting to apply this idea:

"It is very difficult to provide the water service to this big number of LGUs. The only solution is to create water entities that consolidate a considerable number of LGUs." (IM2)

"There is always an idea raised to divide Palestine administratively into four regions, three in the WB and one in GS. However, there are many obstacles to the consolidation notion." (FG2)

"We worked on the idea of merging local bodies, but it is not that easy. Beliefs are one thing and execution on the ground is another." (FG1) 
The consolidation notion does necessarily reflect the centralization system. It can be incorporated within the decentralized system. Notably, LGUs do not believe in a full centralization system but they call for something in between.

"I call for a structure suited between centralization and decentralization so that we preserve the privacy of each area, meanwhile, concerning the overall interest. If there are enough resources, I advocate full decentralization". (FG3)

Obviously, decentralization requires certain institutional capabilities. If unavailable, less institutional empowerment and more inefficiency will be observed:

"When the performance of a municipal council is weak due to many reasons, we can't give more powers to this municipality. We cannot be fully decentralized if the municipality cannot perform its functions properly. ... The fact that a large number of people do not pay their financial dues to LGUs has impacted their functions to deliver services". (FG1)

Other interviewees went into greater detail in their analysis of the LG structure. According to them, the current structure can be classified as a hybrid one, having both centralized and decentralized forms:

".... governors directly follow the president; they have security and supervisory powers.... Governors' roles should not be centralized..... On the other hand, municipal councils are decentralized. They came through election. Some municipalities, particularly the big ones have broad powers (more decentralized) while small municipalities have limited powers (more centralized)." (EX1)

"Even though local elections relatively reflect democratic decentralization, local councils still need and seek centralized financial support." (IM1)

Being a hybrid structure does not necessarily reflect a pre-determined legal framework. The centralization characteristics shown above have no legal basis. Hence, the current LG structure can best be described as follows:

"Chaotic hybrid structure, it is not an organized structure." (EX1)

\section{Weak Institutional Integration}

An effective LG institutional framework requires the integration of different actors. Nevertheless, it seems that actors are concerned with their institutions more than the service delivery process itself. Hence, it is expected that LG functions and structure get negatively affected:

"The water laws do not take into consideration the LG laws and vice versa. Each ministry says this is theirs. Even with the Water Law 2014, it has disintegrated between the WSRC and the Water Authority." (FG2) 
Furthermore, some institutions seem to not play their roles in order to avoid certain problems. Eventually, other institutions will bear responsibility leading into further consequences as is what happened regarding electricity; it was withdrawn from the LGUs:

"One of the responsibilities of the governorate is to intervene when debt is not paid by inhabitants. However, they do not do this as they prefer not to face people and maintain a good relationship with them. One of the motives behind withdrawing the electricity service from LGUs to companies was the inability of collecting arrears". (EX1)

\section{Governance under Occupation}

Due to the Oslo Accords of 1993, Israel maintained its security and administrative control of over 60 percent of the WB, in a locale called Area C (Saleh, 2014, p. 78). Area $C$ was agreed to be returned to the Palestinians as a part of the PLO-Israeli negotiation, yet this has failed to materialize. Furthermore, Palestinians, according to the Oslo Accords, were to have control over the remaining 40 percent of the WB (Area A and B). Israel, however, invades these areas arbitrarily so this complex political situation results in no real Palestinian sovereignty over their resources:

"The Israeli occupation would not allow Palestinians to control any of the fundamental resources, mainly water and electricity. Simply because it does not want to give any aspect of sovereignty for Palestinians... We have first to agree that our main problem is embodied in not having sovereignty and the control over our resources." (FG2)

The absence of Palestinian sovereignty over their natural resources has clearly impacted the structure and function of LG as well as the service delivery process in general:

"No real local governance would exist if we do not control our resources, everything would be impacted". (FG5)

"Israel controls 85 percent of the water resources and almost all energy resources. This imposed on us a certain form of LG structure. For example, the West Bank Water Department was created to coordinate the provision of water from Israel to local councils." (FG4)

The following excerpt reflects the perception of how Israel contributes to obstructing the consolidation of fragmented LGUs, which consequently impedes more efficient structure:

"The proposal for merging was cancelled repeatedly, simply because of the fear that Israel will find it easier to control these regions, and also because we don't have the sovereignty to make benefits of natural resources in these areas." (EX1)

In elaborating on how the Israeli occupation impacts LGU functions, consider the following excerpts: 
"Our role has changed from producing the natural resource and then distributing services into buying from Israel and then distributing. This impacted our functions and the form of the structure applied". (EX1)

"Israel does not allow local councils to play their role, we are always concerned with what Israelis will do for things they don't like." (FG1)

"No local council has reached to that level of efficiency and capability in administrating services because of the scarcity of resources and lack of control over resources." (FG2)

\section{Discussion}

\section{Centralized or Decentralized System?}

It was emphasized in the theoretical perspectives section that LGs have two primary functions which are local democracy and local efficiency (Aulich, 1999, 2005). As for local democracy, the results showed that the population exercise democracy through selecting their representatives at the Palestinian LG level, which is a reflection of decentralization (UNDP, 1997). However, autonomy is also an essential feature of any LG (Marshall, 1965). Furthermore, various scholars concede that the more important the LGU-owned resources, the more autonomy it commands (King and Pierre, 1991, p. 88; Pratchett, 2004). However, Israel controls almost all natural resources. For example, 85 percent of water resources and nearly all energy resources are controlled by Israel. Therefore, Palestinians have restricted local autonomy. This is one of several factors that encourage the central governmental level to intervene. For example, the PWA and its related institutions coordinate with the Israeli party to purchase and centrally distribute water to LGUs. On the other hand, governors, as representatives of the president, also unsystematically intervene in the function of LGUs. Their intervention essentially contradicts the nature of LG that represents the lower tier of government, as stated previously (Marshall, 1965). Governorates represent the regional level as shown in Figure 4. It is notable that they are appointed and do not have the same capabilities of LGUs. Clearly, this goes against the principle of subsidiary asserted by Cass (1992). Although this situation reflects the attributes of centralization, functionally and structurally, it appears that there is no clear regulative policy that guides the distribution of powers among the central and local level. In this context, the impact of the legal framework can be observed. First, no law or policy exists to regulate the relationship between governorates and LGUs. Second, overlapping laws that were either issued after or before the establishment of PNA are still in effect. Thirdly, the newly issued laws, such as the Water Law 2014, are not followed by necessary regulations to arrange the relationship with LGUs.

To summarise, basic services that are assumed to be provided by LGUs according to the Local Authority Law 1997 are intervened by central level governing bodies such as the PWA for water, PEA for electricity and governorates for any possible service. Even though this reflects centralized system characteristics, LGUs still directly deal with citizens. Additionally, local democracy is still being practiced to a high degree. Hence, the attributes of centralization and decentral- 
ization are observed. Theoretically, they are known as hybrid systems, and they are unorganized. It can therefore be called a "Chaotic Hybrid System" as described by one of the interviewees.

Regarding the local efficiency, it seems that citizens' demands are not fulfilled. Official reports and studies show that there are serious problems associated with services delivered. They are generally at different degrees of challenges related to limited access to services, poor quality, low satisfaction level and other issues. Table 4 indicates some of these problems related to water, wastewater, solid waste, electricity and road construction.

\section{Table 4}

\section{Problems Related to the Infrastructure Services Provided by LG}

\begin{tabular}{|c|c|c|c|}
\hline Type of Service & Access to Service & Quality of Service & Level of Satisfaction \\
\hline Water & $\begin{array}{l}52 \text { percent of localities } \\
\text { in WB endured cuts } \\
\text { in the water supply }\end{array}$ & $\begin{array}{l}\text { More than } 90 \text { per cent } \\
\text { of the water pumped } \\
\text { from the aquifer have } \\
\text { salinity exceeding the } \\
\text { WHO standard }\end{array}$ & $\begin{array}{l}53 \text { percent are satisfied } \\
\text { with piped water }\end{array}$ \\
\hline Wastewater & $\begin{array}{l}30 \text { percent of the } \\
\text { households in WB are } \\
\text { connected to a piped } \\
\text { sewage network }\end{array}$ & $\begin{array}{l}\text { Around } 70 \text { per cent } \\
\text { of sewage networks } \\
\text { are old and } 42 \text { per cent } \\
\text { are inefficient }\end{array}$ & $\begin{array}{l}60 \text { percent were } \\
\text { satisfied with the } \\
\text { quality of the service }\end{array}$ \\
\hline Solid waste & $\begin{array}{l}25 \text { percent } \\
\text { of households in the } \\
\text { small villages of WB } \\
\text { have access to solid } \\
\text { waste collection } \\
\text { services }\end{array}$ & $\begin{array}{l}31 \text { percent of localities } \\
\text { have their dump sites } \\
\text { distance from a locality. } \\
\text { Most of cities and } \\
\text { villages burn solid waste } \\
\text { in open dumping }\end{array}$ & $\begin{array}{l}\text { Half of the population } \\
\text { in WB are satisfied } \\
\text { with the availability } \\
\text { of street bins }\end{array}$ \\
\hline Electricity & $\begin{array}{l}31 \text { percent of localities } \\
\text { has non-served areas }\end{array}$ & $\begin{array}{l}\text { Nearly } 43 \text { percent } \\
\text { of localities had weak } \\
\text { electricity current due } \\
\text { to the old existing } \\
\text { networks }\end{array}$ & $\begin{array}{l}34 \text { percent were } \\
\text { satisfied with the cost } \\
\text { of electricity }\end{array}$ \\
\hline Road Construction & $\begin{array}{l}\text { Most inhabitants can } \\
\text { access roads }\end{array}$ & $\begin{array}{l}\text { Irregular road cleaning } \\
\text { is the main issue for } \\
\text { households }\end{array}$ & $\begin{array}{l}45 \text { percent are satisfied } \\
\text { with road services }\end{array}$ \\
\hline
\end{tabular}

Source: Compiled from ALPHA (2013); UNDP (2014); PCBS and MoLG (2015); The World Bank (2017b, 2017a).

It is argued in this context that a trade-off exists between local democracy and local efficiency which is consistent with the belief of scholars such as Dollery, (2009). Furthermore, local democracy should not be merely measured by conducting elections. It appears that there are other elements of local democracy, such as the engagement of the private sector and civil society, missing from the Palestinian context, as stated before in the Palestinian Local Government Framework section. 


\section{Local government Institutional Structure}

The LG structure can be perceived horizontally and vertically as highlighted in the literature review. In the WB, there are about 430 LGUs within the same LG tier. This is a vast number for an exceedingly small region. Hence, it is a horizontally fragmented structure according to the characteristics mentioned by Goodman (2019). He also highlighted that the fragmented vertical structure, which refers to the number of LG tiers, separates between service production and service provision. The findings of this study indicate consistency with this kind of separation. Furthermore, it seems even more complex. The complexity embodies more than these two processes. First, since Palestinians cannot completely fulfil population needs by merely relying on their limited controlled natural resources, PNA institutions and ministries have no choice but to purchase necessary resources from Israel. Hence, in addition to producing services, the same institutions purchase resources from Israel. For example, the West Bank Water Department produces water from Palestinian wells and purchases it back from Israel, for the LGUs. Noticeably, this added role does not reflect the emergence of a new tier of LG. The second complexity, however, embodies the initiation of a third tier. It is worthwhile to quote one of the interviewees who remarked that, "local councils still need and seek centralized financial support". As elaborated upon in the institutional framework section, MDLF was established in 2004 to coordinate the flow of donor funds to LGUs which means that the LGUs dependency on funds has engendered the emergence of a new service financing process. In 2019 alone the MDLF supported LGUs with 58 million usd (MDLF, 2020). Hence, whether services are produced by Palestinians or purchased from Israel, financial support is still needed first. Subsequently, the LG is vertically fragmented with added processes, which involve purchasing resources from Israel and financing the LGUs to provide the services. The structure hence could be described as "Altered Fragmented Structure". Figure 5 demonstrates it clearly.

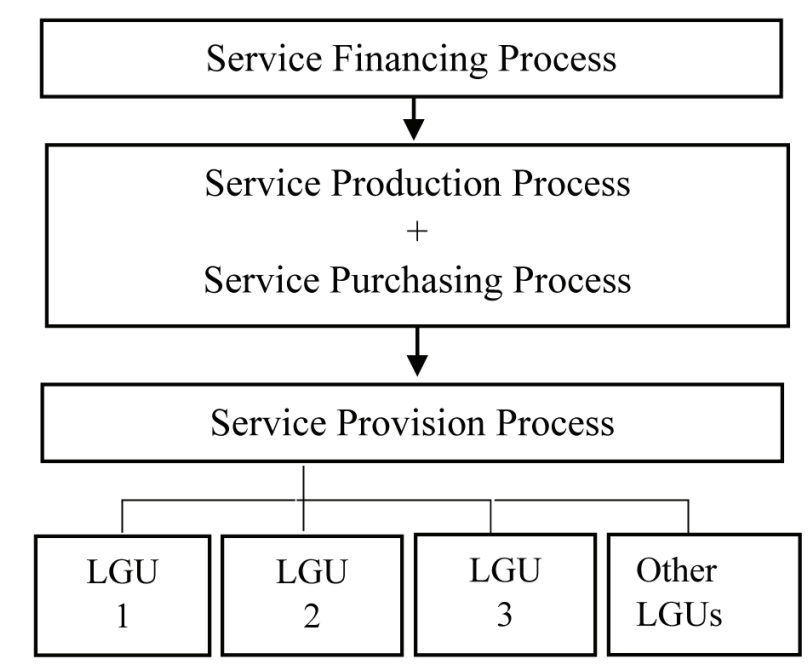

Figure 5: The Palestinian altered fragmented structure.

Source: Compiled by the authors. 
Based on Figure 5, it is easily concluded that the adopted structure does not reflect the institutional reformist perspective, which calls for vertical and horizontal consolidation (Ostrom, 1972). Indeed, it reflects the Public Choice Theory perspective, which advocates for horizontal and vertical fragmentation. In concurrence with the general interviewee perspective, the horizontal fragmented structure, which embodies vast LGUs, although indicative of local democracy, negatively impacts efficiency. Hence, a democracy/efficiency trade-off seems to exist, as indicated in the literature review (Soul and Dollery, 2000). In the light of the fact that most resources are controlled by Israel, reform is bound by this fact. Subsequently, having a consolidated structure where each LGU produces and provides its various services independently, appears to be an impossibility. This means that the current vertical structure wherein service production and service provision are separated is the only available choice. Granting that, the large numbers of LGUs seem unjustified. Local democracy is not necessarily associated with the existence of nearly 430 LGUs. Inhabitants can still elect their representatives with a smaller number of LGUs. Perhaps, only half of them is needed. It will still be a fragmented structure but with more efficiency. If this occurs, there would be no trade-off between the local democracy and efficiency as Berry $(2008,2009)$ discussed, or at least it would be better than the current one (Ayeko-Kümmeth, 2015).

To implement the strategy of consolidating the LGUs into a smaller number, it requires the Palestinian Legislative Council (PLC) to issue a law. However, the PLC was deactivated due to the Israeli arrests of Hamas members of the PLC after it won the election in 2006. The Palestinian President Mahmoud Abbas has also announced the dismissal of the PLC in 2018. Despite these facts, the executive body has the power to issue decrees which compensate for the absence of the PLC (Alsarghali, 2021). However, this power was used to politically centralize the authority within the executive body and relatively ignored issuing administrative decrees to develop the performance of service delivery such as regulations needed to implement the Water Law 2014. Moreover, decrees have been issued by the president to also control the judiciary, specifically the Constitutional Court which has become an extension of the executive power. This resulted in weakening and damaging the judiciary (Shikaki, 2021). Therefore, it is concluded that powers are not distributed equally among the executive, legislative and judicial bodies. It is the executive body which seems to control all powers, particularly after 2006. This is consistent with the finding that fragile states normally experience a tension where one power overcomes other powers (Salter, 2021).

\section{Conclusion}

An essential understanding in the public administration field is that the institutional framework should reflect the legal framework (Rosenbloom, 1986; Bodansky, 1995; Hannam and Boer, 2002; Penning et al., 2002). Nevertheless, the results of this study empirically demonstrate that there is a gap between the legal and institutional frameworks of the Palestinian LG and that the former 
works as an essential input for the later. Although this concurs with previous studies (Jarbawi, 1996; Salameh, 2009), this study looked at the structural and functional aspects of LGUs, which appear to be the most negatively impacted by elements in the governance process. Indeed, public administration is reflected in structures and functions (Rosenbloom, 2013). These two elements are a mirror for local efficiency (Hearfield and Dollery, 2009). Granting that, the Palestinian LG can be considered inefficient. Moreover, local democracy is the other fundamental characteristic of LG (Aulich, 1999). The results show that representatives of LGUs come via election, which indeed reflects local democracy. Therefore, to enhance the LG structure, both LGU consolidation and decrees that re-arrange the institutional relationship in an improved fashion are recommended.

Future studies should seek to build upon the themes mentioned here and to quantitatively measure the legal and institutional issues investigated herein. Furthermore, this study focused on exploring the WB. Future research should also examine the LG institutional framework in the GS. Although they look similar, the distinct context of Gaza deserves to be independently studied. Likewise, in order to understand the comprehensive context, future research should investigate the institutional framework at other institutions related to the LG, such as the PWA. Moreover, it is suggested that policy makers conduct a parliamentary election so that the separation of powers can be enhanced, and that the local government framework can be restructured. Perhaps the most important action which needs to be taken is to decrease the number of the service providers. It is also suggested that the civil society and private sector engage in delivering the infrastructure services which should also contribute to replacing some of the large number of service providers. Further, policy makers should set up clear guidelines, regulations and laws to manage the relationship between private sector and NGO with the LGUs.

Declaration of interest statement: There is no conflict of interest.

\section{REFERENCES}

Abdul Ati, S. (2005) 'Local government and local authorities in Palestine', Al Mezan Center For Human Rights, p. 60. Available at: http://www.mezan.org/uploads/files/2488.pdf (accessed 15 November 2017).

Advisory Commission on intergovernmental relations (1974) The Challenge of Local Government Reorganization. Washington, D.C: Advisory Commission on Intergovernmental Relations.

Al-Habil, W. (2008) Occupations, a diaspora, and the design of local governments for a Palestinian state. Cleveland State University. Available at: https://etd.ohiolink.edu/rws_etd/ document/get/csu1226688053/inline (accessed 18 October 2018). 
ALPHA International (2013) MDP-I client and citizen satisfaction survey. Ramallah. Available at: http://www.mdlf.org.ps/Files/Docs/Clients and citizens satisfaction assessment.pdf (accessed 18 October 2018).

Alsarghali, S. (2021) The dissolution of the Palestinian legislative council by the Palestinian Constitutional Court: A missed opportunity for reform, 2021 posts. Available at: https:// blog-iacl-aidc.org/2021-posts/1-7-21the-dissolution-of-the-palestinian-legislative-council (accessed 19 August 2021).

Andrews, R. et al. (2007) 'Centralization, organizational strategy, and public service performance', Journal of Public Administration Research and Theory. Oxford University Press, 19(1), pp. 57-80. DOI: https://doi.org/10.1093/jopart/mum039.

Aulich, C. (1999) 'From convergence to divergence: Reforming Australian local government', Australian Journal of Public Administration. John Wiley \& Sons, Ltd, 58(3), pp. 12-23. DOI: $10.1111 / 1467-8500.00101$.

Aulich, C. (2005) 'Australia: Still a tale of cinderella', in Denters, B. and Rose, L. E. (eds) Comparing local governance: Trends and developments. Palgrave MacMillan, Basingstoke, pp. 193-210. DOI: 10.1007/978-0-230-21242-8_12.

Ayeko-Kümmeth, J. (2015) The politics of public policy decisions in local government in Uganda. Bayreuth University. Available at: https://epub.uni-bayreuth.de/2053/1/20150515 Final PhDThesis Publication CopyDN.pdf (accessed 18 October 2018).

Berry, C. R. (2008) 'Piling on: Multilevel government and the fiscal common-pool', American Journal of Political Science. John Wiley \& Sons, Ltd, 52(4), pp. 802-820. doi: 10.1111/j.1540-5907.2008.00344.x.

Berry, C. R. (2009) Imperfect union: Representation and Taxation in multilevel governments. Cambridg: Cambridge University Press.

Birkland, T. A. (2006) 'Agenda setting in public policy', in Fischer, F., Miller, G. J., and Sidney, M. S. (eds) Handbook of public policy analysis. Boca Raton: CRC Press, pp. 89-104.

Bodansky, D. (1995) 'Customary (and not so Customary) international environmental law’, Indiana Journal of Global Legal Studies. HeinOnline, 3(1), pp. 105-119.

Boyne, G. (1992) 'Local government structure and performance: Lessons from America?', Public Administration. John Wiley \& Sons, Ltd, 70(3), pp. 333-357. DOI: 10.1111/ j.1467-9299.1992.tb00942.x.

Boyne, G. (1995) 'Population Size and economies of scale in local government', Policy \& Politics. Policy Press, 23(3), pp. 213-222. DOI: https://doi.org/10.1332/030557395782453446.

Burdess, N. and O’Toole, K. (2004) 'Elections and representation in local government: A Victorian case study', Australian Journal of Public Administration. John Wiley \& Sons, Ltd, 63(2), pp. 66-78. DOI: 10.1111/j.1467-8500.2004.00379.x.

Cass, D. Z. (1992) 'Word that saves maastricht-The principle of subsidiarity and the division of powers within the European Community', Common Market Law Review. HeinOnline, 29(6), pp. 1107-1136. 
Christopher, G. (2019) 'Local government fragmentation: What do we know?', State and Local Government Review, 51(2), pp. 134-144. DOI: 10.1177/0160323X19856933.

Committee for Economic Development (1970) Reshaping government in metropolitan areas: A statement on national policy. New York.

Dollery, B. (2010) 'Are there tensions between democracy and efficiency in local government? A conceptual note on the structural reform debate', Urban Policy and Research. Routledge, 28(1), pp. 117-123. DOI: 10.1080/08111140903552704.

Ezbidi, B. (2010) Towards formulating a vision for local government in Palestine, ministry of local government-palestine. Available at: http://www.molg.pna.ps/studies/LGSystemsComparativeStudy-ArabicFinalOct2009.pdf (accessed 19 August 2021).

Goldsmith, M. (2002) 'Central control over local government - A Western European comparison’, Local Government Studies. Routledge, 28(3), pp.91-112. DOI: 10.1080/ 714004150 .

Goldsmith, M. and Page, E. (1987) Central and local government relations: A comparative analysis of West European unitary states. London: Sage London.

Hannam, I. and Boer, B. (2002) Legal and institutional frameworks for sustainable soils: A preliminary report. Bonn: International Union for Conservation of Nature IUCN. Available at: https://poseidon01.ssrn.com/delivery.php?ID $=068096001126026108075084$ 1171171151171220110050350100281040891010241230190740050690910310070000420 3300702707912510212600112004001301108302308110608710212712006704003501406 40940230780221140020660940891160820660250 (accessed 19 August 2021).

Hearfield, C. and Dollery, B. (2009) 'Representative democracy in Australian local government', Commonwealth Journal of Local Governance, 2, pp. 61-75. DOI: https://doi.org/ 10.5130/cjlg.v0i2.1008.

Hsiba, S. (2006) The current status and strategies for the development of local administration in Palestinian territories. Al-Najah National University.

Humphreys, D. (2021) 'Judicial interpretation of legislative silence gone too far: The Case for a separation of powers amendment', SSRN 3775006. Available at: https://ssrn.com/ abstract=3775006 or http://dx.doi.org/10.2139/ssrn.3775006 (accessed 19 August 2021).

Isma'il, A. K. (2005) The role of local Palestinian bodies in promoting participation and political development. Al-Najah National University.

Jarbawi, A. (1996) What kind of local authority do we need? Nablus: Palestinian Research and Studies Center.

King, D. S. and Pierre, J. (1991) Challenges to local government. London: SAGE Publications Limited.

Klassen, A. J. and Brown, J. T. (2018) 'Disadvantage and democracy: Why income and education matter for attitudes towards democracy1', in IPSA 25th World Congress of Political Science. 
Krunz, A. (2009) Local planning in the West Bank. An analytical study towards an acceptable local planning approach. Birzeit University.

Mackenzie, janice A. (2020) 'Using a semi-structured interview to assess capacity', in janice A. Mackenzie, K. E. W. (ed.) Assessing mental capacity: A handbook to guide professionals from basic to advanced practice. Routledge, p. 12. Available at: https://books. google.com.tr/books?hl=en\&lr=\&id=UCnhDwAAQBAJ\&oi=fnd \&pg $=\mathrm{PT} 125 \& \mathrm{dq}=$ Using+a+Semi-Structured+Interview+to+Assess+Capacity.+In+K.+E.+W.+janice+A. +Mackenzie+(Ed.)\&ots=ZADA1RtbJ4\&sig=F1a7YtQ8ZjZGwhXwDf2aieDXKAQ\&red ir_esc $=\mathrm{y} \# \mathrm{v}=$ onepage\&q\&f=false (accessed 19 August 2021).

Marshall, A. H. (1965) Local government in the modern World. London: University of London, Athlone Press.

McDonnell, J. (2019) 'Municipality size, political efficacy and political participation: A systematic review', Local Government Studies. Routledge, 46(3), pp. 331-350. DOI: 10.1080/03003930.2019.1600510.

Ministry of Local Government (MoLG) (2020) Ministry of local government - Palestine. Available at: http://www.molg.pna.ps/Default.aspx (accessed 05 June 2020).

Municipal Development and Lending Fund (MDLF) (2020) Municipal Development and Lending Fund - Annual Report 2019. Ramallah. Available at: https://www.mdlf.org.ps/ Files/Docs/AnnualReports/MDLF Annual Report 2019.pdf (accessed 19 August 2021).

New Vision Firm (2009) Study of public private partnership in the municipalities. Ramallah.

Ostrom, E. (1972) 'Metropolitan reform: Propositions Derived from two traditions', Social Science Quarterly. JSTOR, 53(3), pp. 474-493. DOI: https://www.jstor.org/stable/42860228.

Palestinian Central Bureau of Statistics (PCBS) and Ministry of Local Government (MoLG) (2015) Local Communities Survey, 2015 Main Findings. Ramallah. Available at: http://www.pcbs.gov.ps/Downloads/book2161.pdf (downloaded 05 June 2021).

Palestinian National Authority (PNA) (1997) The 1997 Local Authorities Law. Palestine. Available at: http://muqtafi.birzeit.edu/pg/getleg.asp?id=12358 (accessed 18 October 2018).

Panday, P. (2011) 'Local government system in Bangladesh: How far is it decentralised?', Lex Localis-Journal of Local Self-Government, 9(3), pp. 205-230. DOI: 10.4335/9.3.205-230 (2011).

Panday, P. (2017) 'Decentralisation without decentralisation: Bangladesh's failed attempt to transfer power from the central government to local governments', Asia Pacific Journal of Public Administration. Routledge, 39(3), pp. 177-188. DOI: 10.1080/23276665.2017.1363940.

Penning, de V. et al. (2002) Integrated land and water management for food and environmental security. Colombo. Available at: https://core.ac.uk/download/pdf/39844873.pdf (downloaded 05 June 2021).

Pratchett, L. (2004) 'Local autonomy, local democracy and the "new localism"', Political Studies. John Wiley \& Sons, Ltd, 52(2), pp. 358-375. DOI: 10.1111/j.1467-9248.2004. 00484.x. 
Rosenbloom, D. (1986) Public administration: Understanding management, politics, and law in the public sector. 8th edn. New York: McGraw-Hill Higher Education.

Rosenbloom, D. (2013) 'Reflections on "Public administrative theory and the separation of powers", The American Review of Public Administration. SAGE Publications Inc, 43(4), pp. 381-396. DOI: 10.1177/0275074013483167.

Sabri, N. R., Jaber, R. and Hanya, D. (2010) 'PPPs in Palestinian municipal activities as perceived by stakeholders', Problems and Perspectives in Management, 8(4), pp. 4-19.

Salameh, E. A. (2009) Capacity of the governance structure of Palestine to undertake local economic development. University of Illinois.

Saleh, M. (2014) History of Palestine. Translated by Falah Foundation. Biuret: Al-Zaytouna Centre for Studies and Consultations.

Saunders, M. N. K., Lewis, P. and Thornhill, A. (2009) 'Research methods for business students', in Understanding research philosophy and approaches to theory development. 5th edn. India: Pearson Education limited. Available at: https://www.researchgate. net/publication/330760964_Research_Methods_for_Business_Students_Chapter_4_ Understanding_research_philosophy_and_approaches_to_theory_development (downloaded 05 June 2018).

Sharma, G. (2017) 'Pros and cons of different sampling techniques', International journal of applied research, 3(7), pp. 749-752. Available at: https://www.allresearchjournal.com/ archives/2017/vol3issue7/PartK/3-7-69-542.pdf (accessed 19 August 2021).

Shikaki, K. (2021) Can a newly elected parliament repair the damage done to the Palestinian Political system in its absence? Available at: https://www.pcpsr.org/sites/default/files/ Brief 1_2021_Shikaki on elections and PA reforms English transl.pdf (accessed $19 \mathrm{Au}$ gust 2021).

Shtayyeh, M. and Habas, U. (2004) Municipalities and local government units in Palestine origin, function and their role in economic development. Jerusalem: Palestinian Economic Council for Development and Reconstruction (PECDAR).

Signoles, A. (2010) Local government in Palestine. Paris, France: French Development Agency. Available at: https://www.afd.fr/en/ressources/local-government-palestine (accessed 19 August 2021).

Singaravelloo, K. (2013) 'Local government and intergovernmental relations', in Siddiquee, N. A. (ed.) Public Management and Governance in Malaysia: Trends and transformations. Routledge, pp. 140-160.

Soul, S. and Dollery, B. (2000) 'The effect of municipal population size on political effectiveness: An empirical note on four local government jurisdictions in New South Wales', Regional Policy and Practice. Australian and New Zealand Regional Science Association Inc, 9(2), p. 64.

The Central Elections Commission (2019) A guide to the electoral boundaries of local bodies. Ramallah. Available at: https://www.elections.ps/Portals/0/2019DirectoryOfLocalAut horities.pdf (accessed 19 August 2021). 
The World Bank (2017a) Securing energy for development in the West Bank and Gaza- Brief. Available at: https://www.worldbank.org/en/country/westbankandgaza/brief/securingenergy-for-development-in-west-bank-and-gaza-brief (accessed 18 October 2018).

The World Bank (2017b) The performance of Palestinian local governments. Washington, DC. Available at: https://openknowledge.worldbank.org/bitstream/handle/10986/27518/ FINAL-LGPA-Report-for-portal-June-15-2017-RA.pdf? sequence=5\&isAllowed=y (accessed 18 October 2018).

Tiebout, C. M. (1956) 'A Pure Theory of Local Expenditures', Journal of Political Economy. The University Press of Chicago, 64(5), pp. 416-424. DOI: 10.1086/257839.

UNDP (1997) Decentralized governance programme: Strengthening capacity for peoplecentered development. New York.

United Nations Development Programme (UNDP) (2014) Development for Empowerment: The 2014 Palestine Human Development Report. New York. DOI: 10.1080/ 01619563709535374 .

Yang, H. (2021) 'Institutional development of urban cross-departmental coordination', in Urban governance in transition. Springer, pp. 133-149.

Zaring, D. (2020) 'Toward separation of powers Realism', Yale J. on Reg. HeinOnline, 37, p. 708.

The article was submitted: 08.02.2021; approved after reviewing: 30.07.2021; accepted for publication: 28.11.2021. 